\title{
Over-optimistic Official Forecasts and Fiscal Rules in the Eurozone
}

\section{Citation}

Frankel, Jeffrey A., and Jesse Schreger. "Over-optimistic Official Forecasts and Fiscal Rules in the Eurozone." Review of World Economics (published online, February 14, 2013).

\section{Published Version}

http://dx.doi.org/10.1007/s10290-013-0150-9

\section{Permanent link}

http://nrs.harvard.edu/urn-3:HUL.InstRepos:9804488

\section{Terms of Use}

This article was downloaded from Harvard University's DASH repository, and is made available under the terms and conditions applicable to Open Access Policy Articles, as set forth at http:// nrs.harvard.edu/urn-3:HUL.InstRepos:dash.current.terms-of-use\#OAP

\section{Share Your Story}

The Harvard community has made this article openly available.

Please share how this access benefits you. Submit a story.

Accessibility 


\title{
Over-optimistic Official Forecasts and Fiscal Rules in the Eurozone

\author{
Jeffrey Frankel and Jesse Schreger \\ Harvard University
}

Revised January 10, 2013

Forthcoming, Review of World Economics (Weltwirtschaftliches Archiv) 149, no. 2, 2013. The authors acknowledge support from the Smith Richardson Foundation, though views and findings are ours alone. We thank Raul Galicia Duran for capable research assistance, Roel Beetsma and Martin Muhleisen for sharing their data, Max Otto and Snezhana Zlatinova for suggesting the use of EU data on national fiscal rules, and an anonymous referee for comments.

\begin{abstract}
Eurozone members are supposedly constrained by the fiscal caps of the Stability and Growth Pact. Yet ever since the birth of the euro, members have postponed painful adjustment. Wishful thinking has played an important role in this failure. We find that governments' forecasts are biased in the optimistic direction, especially during booms. Eurozone governments are especially over-optimistic when the budget deficit is over the $3 \%$ cap at the time the forecasts are made. Those exceeding this cap systematically but falsely forecast a rapid future improvement. The new fiscal compact among the euro countries is supposed to make budget rules more binding by putting them into laws and constitutions at the national level. But biased forecasts can defeat budget rules. What is the record in Europe with national rules? The bias is less among eurozone countries that have adopted certain rules at the national level, particularly creating an independent fiscal institution that provides independent forecasts.
\end{abstract}

JEL classification numbers: E62, H50

Keywords: budget, discipline, euro, Europe, eurozone, fiscal, fiscal compact, forecast, independent, institutions, Maastricht criteria, optimism, procyclical, rule, Stability and Growth Pact, wishful thinking 


\section{Introduction}

Fiscal rules are increasingly proposed as a means of reining in excessive budget deficits. By now it is clear to all that the Stability and Growth Pact (SGP) has failed to keep budget deficits and debt levels of eurozone members within the limits specified: originally $3 \%$ of GDP and $60 \%$ of GDP, respectively. In response to the euro crisis that began in 2010, German Chancellor Angela Merkel has proposed and won acceptance for a new Fiscal Compact among the euro states. The goal of the compact is to strengthen fiscal rules among euro members, in particular by writing them into laws and constitutions at the national level.

In any effort to revise or strengthen fiscal rules, it would help to know why some rules have failed in the past, such as the SGP itself, and what the record with national rules of various

sorts is: limits on spending vs. deficits, conditional or unconditional, with or without independent fiscal agencies, and so forth.

One factor behind excessive budget deficits worldwide is a tendency for official forecasts of growth rates, tax receipts, and budget balances to be over-optimistic. It stands to reason that a government that foresees, or claims to foresee, healthy surpluses in coming years is less likely today to take the difficult steps that might be necessary to strengthen the budget, such as cutting spending and raising tax rates.

The bias toward optimism in fiscal forecasts among the 24 countries included in this study is $0.28 \%$ of GDP at the one-year horizon, $0.93 \%$ of GDP at the two-year horizon, and $1.90 \%$ at the three-year horizon. For the 17 European countries, the bias is even higher, despite the rules of the SGP (or perhaps because of them): $0.52 \%$ at the one-year horizon, $1.29 \%$ at the 
two-year horizon and $2.4 \%$ at the three-year horizon. ${ }^{1}$ An important component of the overoptimism in official forecasts of the budget deficit is over-optimism in official forecasts of GDP. ${ }^{2}$

\title{
1.1 Literature Review
}

\author{
Fiscal rules
}

Many experts and some elected officials have suggested that annual deficits and longterm debt can best be held in check through fiscal policy rules or mechanisms such as deficit or debt caps. ${ }^{3}$ Some countries have already enacted laws along these lines. The most important and most well-known example is the fiscal rules of the eurozone, which supposedly limit budget deficits to $3 \%$ of GDP and debts to $60 \%$ of GDP. ${ }^{4}$ (The Maastricht Treaty specified these fiscal rules as criteria for determining what countries are admitted to the eurozone. The SGP supposedly dictated that member countries must continue to meet the criteria.) Some euro countries have enacted budget rules at the national level.

Other countries have also adopted fiscal rules and other similar institutions. ${ }^{5}$ In a recent IMF Working Paper, Schaechter, et. al. (2012) create a new database of national and supranational fiscal rules across 81 countries from 1985 to 2012 . The authors report that while only five countries had fiscal rules in place in 1990, 76 countries had them in place by the end of March 2012, most of them purporting to put limits on the deficit or debt. The success of these

1 The averages are the unweighted averages of each of the country means. Each country mean receives the same weight, even if some countries have more observations.

${ }^{2}$ These findings are documented by Frankel (2011b) and other authors cited in the literature review below.

${ }^{3}$ Anderson and Minarik (2006), Persson and Tabellini (2004), Poterba (1997), Wyplosz (2005), IMF Fiscal Affairs Department (2009).

${ }^{4}$ Buti et al. (1998) or Debrun et al (2008).

${ }^{5}$ Alesina et al. (1999), Kopits (2001), Kopits, Symansky (1998), Milesi-Ferretti (2004). 
measures, however, depends on making accurate forecasts of government spending and revenues. Getting those forecasts right has proven to be very difficult for most governments.

\section{Research on Official Fiscal Forecasting}

Econometric studies have already shown that government budget forecasts in many countries are over-optimistic on average, often because official estimates of economic growth are overoptimistic.

Auerbach (1994) finds over-optimistic official U.S. forecasts in the decade up to 1993. McNees (1995) finds an optimistic bias in official forecasts of long-term American growth through 1994. Auerbach (1999) again finds a tendency for US Office of Management and Budget (OMB) forecasts to overestimate revenues during the period 1986-93, but found a tendency to underestimate revenues during the subsequent period, 1993-99. McNab, Rider, and Wall (2007) find that OMB's one-year ahead forecasts of US tax receipts were biased over the period 1963-2003 and suggest that the bias may have been strategic on the part of various administrations seeking to achieve particular goals, such as overstating budget balance when the administration is seeking to increase spending or cut taxes. Frendreis and Tatalovich (2000) show that US administrations (OMB) are less accurate in estimating growth, inflation and unemployment than is the independent Congressional Budget Office or the Federal Reserve Board. They find partisan bias, interpreted as Republican administrations over-forecasting inflation and Democratic administrations over-forecasting unemployment.

Forni and Momigliano (2004) find optimism bias among OECD countries in general. Ashiya $(2005,2007)$ shows that official Japanese growth forecasts are biased upwards and are significantly less accurate than private sector forecasts. According to O'Neill (2005) and Mühleisen et al, (2005), Canada underestimated its budget deficits in the late 1980s and early 
1990s, but subsequently overestimated them (1994-2004), perhaps to reduce the risk of missing its target of a balanced budget under its strengthened institutional framework.

Jonung and Larch (2006) find that budget agencies in the EU systematically overestimate the economic growth rate. The tendency toward over-optimistic forecasts is especially strong in Italy and Germany. The United Kingdom is an exception. Strauch et al. (2009) find a statistically significant optimism bias for some euro members: Germany, Italy, Greece, Luxembourg, and Portugal for the period 1991-2004. The United Kingdom, Finland and Sweden, on the other hand, tend to overestimate their deficits. In light of this difference, it is suggestive that the United Kingdom and Sweden were not trying to get into the euro, which would have required meeting the fiscal criteria of the 1992 Maastricht Treaty, while the others were trying to get in, and are now there and thus subject to the SGP. ${ }^{6}$ Brück and Stephan (2006) explicitly conclude that eurozone governments have manipulated deficit forecasts before elections since the introduction of the SGP. Most of these authors argue that the systematic over-optimism in ex ante forecasts translates directly into larger ex post deficits, and particularly to deficits larger than targeted under the SGP.

Similarly, Beetsma et al (2009) find that realized budget balances among SGP countries on average fall short of official ex ante plans. Marinheiro (2010) adds another complete business cycle to the data under the SGP, and again finds that the forecasts of European fiscal authorities are systematically too optimistic. This evidence is not consistently strong across the set of 15 EU countries, but the bias is high for France, Italy and Portugal at all forecast horizons. ${ }^{7}$ Beetsma et al (2011) decompose the overall optimism bias in the budget forecasts of EU governments into the component that arises between initial plans and the first release of actual

\footnotetext{
${ }_{7}^{6}$ Indeed, Sweden's strategy for staying out could have been to feign fiscal imprudence!

${ }^{7} \mathrm{He}$ proposes delegating the macroeconomic forecasting to supranational authorities, such as the European Commission or the IMF.
} 
budget numbers and the component that arises between the first release and the final revised budget numbers.

One of the present authors (Frankel, 2011a,b) recently studied forecasts of real growth rates and budget balances made by official government agencies in 33 countries. A number of striking findings emerge. (i) The official forecasts have an upward bias, which is stronger at longer horizons. On average the gap between the forecast of the budget balance and the realized balance is 0.2 percent of GDP at the one-year horizon, 0.8 percent at the two-year horizon, and 1.5 percent at the three-year horizon. (ii) One reason for the optimism bias in official budget forecasts is an optimism bias in forecasts of economic growth. The country's growth rate is an important determinant of the budget balance at all three time horizons, so over-optimism in predicting growth is linked to over-optimism in predicting budget balances. On average, the upward bias in growth forecasts is $0.4 \%$ when looking one-year ahead, 1.1 percent at the twoyear horizon, and 1.8 percent at three years. (iii) The bias is stronger in booms than in normal times. These findings can help to explain excessive budget deficits, and especially the failure to run surpluses during periods of high output: if a boom is expected to last indefinitely, then saving for a rainy day is unnecessary.

Many believe that better fiscal policy can be obtained by means of rules such as ceilings for the deficit. But Frankel (2011a) also finds: (iv) countries subject to a budget rule, in the form of euroland's Stability and Growth Path, make official forecasts of growth and budget deficits that are even more biased and more correlated with booms than do other countries. This effect may help explain frequent violations of the SGP. 


\section{Data on Official Budget Forecasts}

The primary data for this paper come from an expanded version of the data set used in Frankel (2011a). The data set is composed of the official government forecasts in documents for 34 countries. ${ }^{8}$ Of these we have at least one full decade of budget data for 24 countries. The countries with less than a decade of fiscal forecasting data are primarily Central and Eastern European countries that only began publicly providing forecasts when they began submitting Stability and Convergence Programs to the European Commission in 2005. These short time series are almost entirely concentrated around the period of the global financial crisis, 20082012; we exclude them from the analysis to avoid results that might be driven solely by this single unusual historical episode.

Of the remaining 24 countries, the 17 European countries ${ }^{9}$ are the main focus of our analysis. The 7 non-European countries ${ }^{10}$ will be used occasionally, as a standard of comparison. Beginning in 1999, the data for all European Union countries come from the Stability and Convergence Programs that EU members are required to submit annually to the European Commission as part of the SGP. Prior to that, forecasts were taken directly from national budgets. The sample period varies from country to country due to data availability. The starting date ranges from as early as 1977 (for Chile) to as late at 2002 (for Norway); 1999 is the most common starting year for European countries because of the new requirement to submit Stability and Convergence programs to the European Commission. For several European countries, such as France, Italy, Germany and the United Kingdom, forecast data from national budgets become available earlier in the 1990s. The ending date ranges from

\footnotetext{
${ }^{8}$ A list of country coverage can be found in Table A1 of the Online Appendix.

${ }^{9}$ Austria, Belgium, Denmark, Finland, France, Germany, Greece, Ireland, Italy, Luxembourg, the Netherlands, Norway, Portugal, Spain, Sweden, Switzerland, and the United Kingdom.

${ }^{10}$ Australia, Canada, Chile, Mexico, New Zealand, South Africa, and the United States.
} 
2005 (for Switzerland) to 2011 (for 16 countries). The data set contains not only forecasts of the overall budget balance, but also forecasts of real GDP growth, revenues as a percentage of GDP, expenditures as a percentage of GDP, and the inflation rate. In the Stability and Convergence Programs, EU countries are required to provide forecasts at least three years ahead, but the forecasting horizon is often shorter in other countries' budget processes. For instance, Norway only forecasts its budget balance one-year ahead. Summary statistics on the official budget forecasts can be found in Tables A1, A2 and A3 of the Online Appendix. Information on the data sources used throughout the paper can be found in the Data Appendix in the Online Appendix.

The budget balance forecast data used in the analysis are summarized in Table A1 of the Online Appendix. In the table, it can be seen that budget forecast errors exhibit heterogeneous patterns across countries. Figures 1 and 2 plot the mean one and two-year horizon forecast error for each of the countries in sample. The forecast error is defined as forecast budget balance minus actual budget balance, so positive numbers indicate over-optimistic forecasts. In both cases, Greece, Ireland and Portugal are the countries that have the most over-optimistic forecasts. Figure 3 plots the mean budget balance forecast error by year for European countries. The figure shows that while budget forecast errors were particularly large in the wake of the global financial crisis beginning in 2008, budget balances are generally over-optimistic throughout the full sample period. Again, the over-optimism increases with the forecast horizon. Figure 4 plots the equivalent figure for real GDP forecast errors for the European countries.

\section{Influences on Official Forecasts}


In order to understand the sources of budget forecast errors, it is useful to begin by examining how forecasts are affected by macroeconomic variables available contemporaneously, that is, at the time the forecasts are made. To study forecast bias we compare how macro variables explain forecast budget balance improvements and actual changes in the budget balance. ${ }^{11}$ We define the $i$-year budget balance improvement $\left(B B I_{t+i}\right)$ as the change in the budget balance $(B B)$ between time $t$ and $t+i$ :

$$
B B I_{t+i}=B B_{t+i}-B B_{t}
$$

The forecast budget balance improvement $\left(F B B I_{t+i}\right)$ is defined equivalently, with the forecast of the year $t+i$ budget balance replacing $B B_{t+i}$.

Here, we limit ourselves to two explanatory variables: the current budget balance $\left(B B_{t}\right)$ and the output gap $\left(O G_{t}\right)$. To calculate the output gap, log real GDP is HP filtered and the output gap is defined as the cyclical component, that is, log GDP minus the trend component (times 100). Table 1 looks only at European countries. We regress Forecast and Actual Budget Balance Improvements on the current output gap and budget balance:

$$
B B I_{t+i}=\beta_{0}+\beta_{1} B B_{t}+\beta_{2} O G_{t}+\varepsilon_{t+i} .
$$

The main finding in these regressions is that governments forecast too much mean reversion, with $\beta_{1}$ strongly negative and significant for forecast improvements but much less so for actual improvements. The magnitude of $\beta_{1}$ increases with the forecast horizon.

In addition, an excess of current output above trend portends a deterioration in the budget balance in the subsequent year (presumably due to reversion in output), which is not at all captured in the forecast. We find that these two macroeconomic variables - the current budget deficit and output - explain a large fraction of forecast budget balance improvements: for

\footnotetext{
${ }^{11}$ In this paper, we use the revised versions of macroeconomic statistics rather than the statistics that were contemporaneously available because of data availability. For analysis of budget forecast errors using real-time data see Beetsma et. al. (2009).
} 
European countries the $R^{2}$ is 0.41 at the one-year forecast horizon, 0.56 at the two-year forecast horizon, and 0.66 at the three-year horizon. While official government forecasts predict that deficits will be short-lived, the actual budget balance improvements have much lower $\beta_{1}$ coefficients.

In Table 2, rather than including just the simple budget balance at the time the forecast was made, $B B_{t}$, we allow the coefficient on the contemporaneous budget balance to differ depending on whether the budget is in surplus or deficit. Defining Surplus s $_{t}$ as an indicator variable that takes the value of 1 when $B B_{t}$ is greater than or equal to 0 , and Deficit $t_{t}$ as an indicator variable that takes the value 1 when $B B_{t}$ is less than 0 , we run the regression:

$$
B B I_{t+i}=\beta_{0}+\beta_{1} \text { Surplus }_{t} * B B_{t}+\beta_{2} \text { Deficit }_{t}^{*} B B_{t}+\beta_{3} O G_{t}+\varepsilon_{t+i} .
$$

The key finding is that at the one-year horizon, the coefficient $\beta_{2}$ on $\operatorname{Deficit}_{t} * B B_{t}$ is negative and very strongly significant, but the coefficient $\beta_{1}$ on $\operatorname{Surplus}_{t} * B B_{t}$ is insignificantly different than zero. In the short-term, we therefore see that countries forecast their deficits will disappear but do not similarly forecast the end of their surpluses.

In column (2), we see that this prediction is qualitatively correct, as large deficits do predict budget balance improvements but surpluses do not. However, the $\beta_{2}$ coefficient for the forecast improvement is nearly three times as large as for the actual improvements, meaning that while deficits tend to be reduced in the short run, they are not reduced as much as they are forecast to. Interestingly, at the two-year horizon, surpluses and deficits are forecast to be nearly equally mean-reverting, while at the three-year horizon deficits are forecast to contract more quickly than surpluses. Thus, while government forecasts claim that deficits will be quickly eliminated, and this tendency explains a large amount of the variation in their forecasts, in reality these measures are poor predictors of the evolution of the budget deficit. 


\subsection{Forecast Errors}

In this section, we focus explicitly on how current macroeconomic conditions relate to future forecast errors. We define the $i$-year ahead budget balance forecast errors $B B E_{t+i}$ as the forecast budget balance value minus the actual budget balance.

$$
B B E_{t+i}=F B B_{t+i, t}-B B_{t+i}
$$

In the above expression $B B E_{t+i}$ indicates the realized $i$-year ahead forecast error, $F B B_{t+i, t}$ is the budget balance forecast for period $t+i$ made in period $t$, and $B B_{t+i}$ is the realized budget balance in period $t+i$. Much of the remainder of this paper will focus on understanding when countries are systematically over-optimistic in their official budget forecasts (a high value of $\left.B B E_{t+i}\right)$. We begin this exercise in the first three columns of Table 3 by seeing whether macroeconomic variables known at the time the forecast is made (time $t$ ) can predict the size of budget forecast errors.

$$
B B E_{t+i}=\beta_{0}+\beta_{1} B B_{t}+\beta_{2} O G_{t}+\varepsilon_{t+i} .
$$

In columns (1)-(3) of Table 3 we see that large budget deficits at the time a forecast is made on average correspond to forecasts that prove to be over-optimistic. This bias increases with the forecast horizon. In addition, we find further support for the conclusion of Frankel (2011a) that official forecasts are especially subject to wishful thinking during booms, defined here as output being above trend. ${ }^{12}$ For European countries, a $1 \%$ increase in the output gap at the time a forecast is made is associated with a budget forecast that is $0.6 \%$ of GDP too

\footnotetext{
${ }^{12}$ Because the output gap is constructed using the HP filter, future data is used in constructing the contemporary output gap so these are not true predictive regressions. However, these results are generally robust to replacing the output gap with recent GDP growth.
} 
optimistic at the one-year horizon, $1.4 \%$ at the two-year horizon, and $1.9 \%$ at the three-year horizon.

In Table 4, we once again introduce dummy variables for surpluses and deficits to see if surpluses and deficits differentially affect budget forecast errors:

$$
B B E_{t+i}=\beta_{0}+\beta_{1} \text { Surplus }_{t} * B B_{t}+\beta_{2} \text { Deficit }_{t}^{* B B} B_{t}+\beta_{3} O G_{t}+\varepsilon_{t+i}
$$

We find that at all three horizons, $\beta_{2}$ is negatively and strongly significant, confirming that countries with larger budget deficits are more over-optimistic in their forecasts. At the two-year horizon, we again find that countries forecast that their surpluses will shrink more quickly than they do. ${ }^{13}$

In Columns (4)-(6) of Table 3, we repeat this exercise for GDP growth forecast errors. Defining the real GDP growth forecast error as:

$$
G D P E_{t+i}=F G D P R_{t+i, t}-G D P R_{t+i},
$$

where $F G D P R_{t+i, t}$ is the time $t$ forecast of real GDP growth rate in year $t+i$, and $G D P R_{t+i}$ is the actual real GDP growth rate in period $t+i$, we regress $G D P E_{t+i}$ on the contemporaneous output gap and budget balance to see if these current variables can explain the forecasting bias. We include the output gap to examine if governments forecast recessions to end quickly and booms to continue indefinitely. We include the budget balance to examine the possibility that governments may overestimate GDP growth during periods of high deficits so that their budget balance as a percentage of GDP is forecast to improve. As was the case for budget deficits, a large positive output gap is a strong predictor of over-optimistic forecasts; booms are

\footnotetext{
${ }^{13} \mathrm{We}$ also perform the same exercise for two different subsamples: euro area countries and non-euro area countries. Larger current budget deficits are associated with significantly more over-optimistic budget forecasts at all horizons over both the 1999-2007 and 1999-2011 time periods for euro area countries. So the crises of 2008-2011 are not driving these results. (Larger budget deficits are only a predictors of over-optimism at the two-year horizon from 1999-2011 for non-euro area countries). The current output gap is a robust predictor of over-optimistic budget forecasts for both euro area and non-euro area countries, over either period. These results are available from the authors upon request.
} 
unrealistically extrapolated into the future. A contemporary budget deficit is a weaker predictor of over-optimism and is only significant at the two-year horizon. Governments predict that booms will continue longer than they actually do. Those countries with budget deficits have a tendency to wish them away via future growth prospects.

\section{Over-optimism and the Stability and Growth Pact}

Since the previous sections have shown that the contemporaneous output gap $O G_{t}$ and budget balance $B B_{t}$ explain a large fraction of official forecast over-optimism, we include these two variables as controls in all of our subsequent regressions. We examine how a variety of factors, such as the SGP, national fiscal rules or independent budget forecasting institutions modify these baseline results. Because Table 4 suggests that the relationship between the current budget balance and over-optimism is stronger for deficits than surpluses, we also conduct all of our subsequent analysis using a deficit dummy variable times the size of the budget balance (Deficit*BB${ }_{t}$ ). These results, however, are qualitatively similar to the results using the overall budget balance and are therefore relegated to Tables A5, A6, A7, and A8 in the Online Appendix.

Next, we explore how exactly the SGP rules relate to over-optimism in the euro area. Because the SGP forbids EU members to exceed a deficit of 3\% of GDP we hypothesize that governments will be reluctant to forecast breaches of this limit and will instead shade their forecasts into the permissible range and then, if necessary, blame their subsequent violation on events outside their control. While all signatories of the Maastricht Treaty technically agree to abide by the SGP limits on deficits and debt, only euro area countries face the threat of sanctions 
for violations (in theory) or political pressure and embarrassment (in practice). We therefore treat euro area members as the only countries for whom the SGP limits are relevant.

Figure 5 offers visual support for the idea that the SGP makes countries less willing to forecast deficits greater than 3\% of GDP but not necessarily less likely to violate the limit. In all four panels, the vertical line indicates a budget deficit of $3 \%$ of GDP. In the upper left-hand panel, we see that prior to the global financial crisis, only once did a euro area country forecast a violation of the $3 \%$ limit at the two-year horizon, yet there is no such discontinuity for actual budget deficits (upper right-hand panel). For comparison, we include a similar histogram of twoyear forecasts for countries outside the euro area, and the corresponding realizations in the lower right panel. In Table A4, in the Online Appendix, we contrast forecast and actual violations of the 3\% deficit/GDP limit for euro area and non-euro area countries from 1999-2007. At all forecast horizons, euro area countries were less likely to forecast deficits over $3 \%$ even though they actually violated the limit more frequently.

To examine more systematically this idea that countries bound by the SGP try to avoid or postpone reprimands by means of over-optimistic forecasts, in Table 5 we begin by regressing budget forecast errors on the contemporaneous output gap $O G_{t}$ and a dummy variable for membership in the euro area Eurot.${ }^{14}$ We divide Table 5 into two panels, the first for one-year ahead forecast errors and the second for two-year ahead forecast errors. In the first specification within each panel we add a dummy variable for euro area membership to the baseline variables from Table 3, omitting year fixed effects, and in the second we include year fixed effects. As can be seen in these baseline regressions, controlling for the contemporaneous output gap and

\footnotetext{
${ }^{14}$ Because the large majority of the three-year horizon forecast data we have comes from Stability and Convergence Programs, in this section we only look at forecast errors at the one- and two-year horizon to ensure we have sufficient observations from countries outside the euro area.
} 
budget balance, membership in the euro area alone is not associated with a statistically significant increase in budget forecast over-optimism above and beyond that of other countries.

In column (3) of Table 5, we introduce interaction terms between euro area membership and our baseline variables to examine whether euro area membership modifies our baseline results from Table 3. At both the one- and two-year horizons, the coefficient on the interaction between euro area membership and the contemporaneous budget balance is strongly negative and statistically significant while the magnitude of the coefficient on the budget balance is reduced. In other words, we see that the relationship between deficits and over-optimism is stronger for euro area countries than for countries outside the euro area. In the Online Appendix, Table A5 shows the results are even stronger when we restrict ourselves to Deficit $_{t} * B B_{t}$ rather than $B B_{t}$. In that case, an increase in the budget deficit of one percent of GDP is associated with an additional $0.76 \%$ of GDP budget forecast over-optimism for euro area countries at the one-year horizon but no impact for countries outside the euro area. At the two-year horizon the coefficient is -0.68 and significant, but again statistically insignificantly different from zero for non-euro countries.

In column (4) of Table 5, we introduce a dummy variable for violations of the excessive deficit procedure limit, $E D P_{t}$, that takes the value 1 if the country's most recent budget deficit violates the 3\% cap, and an interaction between $E D P_{t}$, and $E u o_{t} .$. We also include year fixed effects to control for common time-varying shocks $\lambda_{\mathrm{t}}$.

$$
B B E_{t+i}=\beta_{0}+\lambda_{t}+\beta_{1} O G_{t}+\beta_{2} B B_{t}+\beta_{3} E D P_{t}+\beta_{4} \text { Euro }_{t}+\beta_{5} \text { Euro }_{t} * O G_{t}+\beta_{6} \text { Euro }_{t} * E D P_{t}+\varepsilon_{t+i} .
$$

The main result concerns the interaction between the dummy variable for membership in the euro area and a violation of the EDP at the time the forecast was made $\left(\beta_{6}\right)$. This coefficient is large and positive in each specification at the one- and two-year horizons: when euro area countries are in violation of the EDP at the time a forecast is made, their one-year forecasts are 
biased by over $1.7 \%$ of GDP more than non-euro violators of the EDP limit. At the two-year horizon, the point estimate is over $2 \%$ of GDP. In other words, even controlling for year fixed effects, the level of the output gap, a dummy for the common bias coming from deficits larger than 3\% of GDP, and interaction terms, euro area countries that make their budget forecasts while in violation of the deficit limit have forecasts that are $1.7 \%$ of GDP more over-optimistic at the one-year horizon than non-euro countries exceeding the $3 \%$ criterion. At the two-year horizon, the effect is even stronger, with euro area countries in violation of the EDP making forecast errors over $2 \%$ of GDP more over-optimistic than other countries with deficits that large.

In the final column of each panel of Table 5, we include both $\operatorname{Euro}_{t} * B B_{t}$ and $\operatorname{Euro}_{t}{ }^{*} E D P_{t}$. The coefficient on $\operatorname{Euro}_{t}{ }^{*} E D P_{t}$ becomes insignificant at the one-year horizon, and both coefficients become insignificant at the two-year horizon. The joint interpretation of the point estimates of coefficients is largely the same, however: euro area countries with large deficits generally have much more optimistic forecasts than other countries. These two variables are, of course, highly correlated.

Next, we construct a new variable EDPGap that measures the size of the violation of the three percent limit, to use in place of the dummy variable. ${ }^{15}$ The variable is defined as the budget balance plus three $\left(B B_{t}+3\right)$ if the budget deficit is more than three percent of GDP and takes the value of zero otherwise. In Table 6, we replace the dummy variable $E D P_{t}$ with this new variable EDPGap and re-run regressions 4 and 5 of Table 5. The coefficient on EDPGap in columns (1) and (3) of Table 6 (representing the one- and two-year horizons) is significant at the one percent level and strongly negative. As in Table 5, the individual coefficients are harder to interpret when the additional interaction between euro area membership and the budget balance

\footnotetext{
${ }^{15}$ We thank an anonymous referee for this helpful suggestion.
} 
is included, but the results are consistent with the conclusion that larger deficits and violations of the SGP threshold are associated with significantly more fiscal over-optimism in euro area countries. ${ }^{16}$

These results provide an enlightening interpretation of the finding in Frankel (2011a) that euro area countries are overall more over-optimistic in their budget deficits. In these regressions, euro area forecast errors are comparable to non-euro area forecasts much of the time, but when the limits set out in the EDP are breached euro members have very large over-optimistic forecast errors. These findings support the idea that when faced with fiscal rules like the SGP, countries find it tempting to adjust their forecasts to meet the criteria, rather than taking the painful actions needed to meet the criteria in reality.

Our bias estimates are quite large. They reflect in part the fact that these countries were hit particularly hard during the 2009 global financial crisis. Nevertheless, the fact that these countries missed their forecasts so much more than other countries is important, especially since the year fixed effects take out the mean effect of the financial crisis on government budgets.

\section{National Fiscal Rules}

In this section, we examine the impact of national fiscal rules on official forecast errors. Even though the eurozone's fiscal compact was only agreed in late 2011, many of the members already had rules at the national level. It should be possible to learn from their experience.

The fiscal constraints of the SGP provide a clear motivation for wishful thinking in the forecasts, in order to avoid the political embarrassment of reprimands if not outright sanctions from a supranational monitoring authority. It is not clear a priori if we should expect the same

\footnotetext{
${ }^{16}$ Because the variable EDPGap is highly collinear with several of the other variables, we prefer the dummy
} variable $E D P$ and will use it in place of EDPGap throughout the rest of the paper. 
sort of pattern for national rules. On the one hand, the country is "grading its own homework." Rather than the sovereign being monitored and disciplined by an external authority removed from domestic politics, national fiscal rules are enforced by branches of the same government that does the forecasting. On the other hand, national law and especially national constitutions may be more binding than international agreements.

\subsection{Fiscal Rule Index}

Before turning to the examination of the impact of different types of fiscal rules on budget balance forecast errors, we briefly describe the indices we use to measure the strength of national fiscal rules. The underlying data on the classification of these rules come from the European Commission's (EC) "Numerical Fiscal Rules in the EU Member States."17 The database provides the data at varied levels of aggregation. At the finest level, it provides details on every individual fiscal rule in each EU member state from 1990 through 2010 (107 individual rules). The European Commission classifies each fiscal rule as either a budget balance rule, debt rule, expenditure rule, or revenue rule. For each rule, the EC also provides a numerical "Fiscal Rule Strength Index" (FRSI). This index is a weighted average of five rule criteria: statutory base of the rule, how much room the rule allows in setting or revising objectives, the nature and independence of the monitoring and enforcement body, the enforcement mechanisms of the rule, and visibility of the rule in the media. ${ }^{18}$

In order to construct an aggregate Fiscal Rule Index (FRI) for each country, the EC then multiplies the FRSI by the fraction of general government finances covered by the rule. If only

\footnotetext{
${ }^{17}$ Available at http://ec.europa.eu/economy_finance/db_indicators/fiscal_governance/fiscal_rules/index_en.htm. The data on national fiscal rules in Europe were also applied to this problem by Zlatinova and Otto (2012).

${ }^{18}$ The FRSI indices use the random weights method as in Sutherland et. al. (2005).
} 
one rule is in force in a country in a given year, this product of the FRSI and the fraction of finances covered is the FRI for the year. If, however, multiple rules apply to the same government sector ${ }^{19}$, they are ranked by the product of the fraction of government finances they cover and their FRSIs; the strongest rule covering each government sector is given a weight of 1 , the second $1 / 2$, the third $1 / 3$, and so on. These weighted rules ${ }^{20}$ are then summed to form the FRI. In the EC index, budget balance rules, debt rules, revenue rules, and expenditure rules are all treated equally in the construction of the aggregate FRI.

These types of rules are conceptually different. Thus, rather than use the composite FRI constructed by the EC, which is what Zlatinova and Otto (2012) do, we construct separate FRI's for budget balance, debt, expenditure and revenue rules. We follow the same process used by the EC in constructing the aggregate index in constructing our four separate indices. We then normalize each of the indices to run between 0 and 1 . For budget balance rules, the United Kingdom's budget balance rule in place from 1997 to 2008 achieved the highest score in sample and is therefore given the value of one in our index. ${ }^{21}$ The budget balance rule index thus runs from 0 (no budget balance rule) to rules comparably strong as the United Kingdom's “Golden Rule." The countries for which we have data on national fiscal rules and sufficient budget forecast data ${ }^{22}$ to include in the regressions are Austria, Belgium, Denmark, Finland, France, Germany, Greece, Ireland, Italy, Luxembourg, the Netherlands, Portugal, Spain, Sweden, and the United Kingdom. Regression results that include specific national fiscal rules are limited to these countries, which are called "EC data set countries" in the regressions.

\footnotetext{
${ }^{19}$ Each rule is classified by the government sector that it covers: the central government, regional governments, local governments and social security. A rule can also be classified as covering multiple sectors or the general government. If one rule covers the general government sector and a second rule covers only certain sectors, the rule covering the individual sector is discounted as if it were the second rule covering that specific sector.

${ }^{20}$ The weighted rules are (rule weight) X (coverage of general government finances) X (FRSI).

${ }^{21}$ The so-called "Golden Rule" restricted the general government to borrow only to finance investment rather than current spending.

${ }^{22}$ As in the previous sections, we require at least 10 budgets.
} 
Figure 6 plots the FRI for budget balance rules, revenue rules, expenditure rules, and debt rules for all of the countries on which we have data.

\subsection{Budget Balance Rules}

Having constructed these indices, we next examine the impact of national budget balance rules on budget forecast errors. In columns (1) and (2) of Table 7, we regress the one- and twoyear budget balance forecast errors on the output gap, budget balance, the budget balance FRI $\left(B B R F R I_{t}\right)$ and interaction terms between the budget balance FRI and the output gap and budget balance. We find that stronger national budget balance rules are associated with a statistically insignificant reduction in the amount of over-optimism in budget forecasts. In addition, neither of the interaction terms are significant at the one- or two-year horizon. Thus, unlike in Table 5, we find that the introduction of national budget balance rules does little to change our baseline results from Table 3 .

In columns (3) and (4) of Table 7, we mirror the euro area regressions of Table 5 by adding a dummy variable for a deficit greater than $3 \%$ of GDP $\left(E D P_{t}\right)$ and an interaction between this dummy and the budget balance fiscal rule index. Although in Table 5 the dummy variable for a $3 \%$ cutoff had the interpretation of violating the bounds of the SGP, the national budget balance rules do not necessarily have the same numerical target. We include the same dummy variable to keep the estimates in Tables 5 and 7 comparable. The key result from these regressions is that whereas euro area countries with deficits larger than $3 \%$ of GDP make much more over-optimistic forecasts, the effect is reversed when it comes to national budget balance rules. Thus, while all countries with budget balances greater than $3 \%$ of GDP generally have over-optimistic forecasts, this bias is reduced but not eliminated by stronger national fiscal 
rules. This effect is in the opposite direction from the case of the supranational SGP, even though the $3 \%$ level is generally not the target of national budget balance rules.

\subsection{Budget Balance Rules and the SGP}

The final issue we address in this section is how exactly national budget balance rules interact with the SGP. To examine this question, in columns (1) and (2) of Table 8 we regress budget balance forecast errors on the contemporaneous output gap, budget balance, the budget balance fiscal rule index, a dummy for membership in the euro area, an interaction between national budget balance rules and euro area membership and year fixed effects:

$$
\begin{aligned}
B B E_{t+i}=\beta_{0}+\lambda_{t .} & +\beta_{1} O G_{t . .}+\beta_{2} B B_{t}+\beta_{2} B B R F R I_{t}+\beta_{3} \text { Euro }_{t}+\beta_{4} B B R F R I_{t} * O G_{t} \\
& +\beta_{5} B B R F R I_{t} * B B_{t}+\beta_{6} B B R \text { FRI }_{t}^{*} \text { Euro }_{t}+\varepsilon_{t+i} .
\end{aligned}
$$

The main result is that while membership in the euro area is associated with more overoptimistic budget balance forecasts (albeit statistically insignificantly), this effect is reduced when euro area membership is combined with national budget balance rules. Although the direct effect of budget balance rules, without conditioning on euro membership, is statistically insignificant (Table 7), the results of columns (1) and (2) of Table 8 imply that national fiscal rules help reduce over-optimism when counteracting the effect of a supranational rule.

Columns (3)-(6) of Table 8 attempt to understand more precisely the nature of the success of national fiscal rules at reducing the bias in euro area forecasts. Since euro area countries are more over-optimistic when they are already in violation of the statutory limit, we examine whether national fiscal rules are effective in eliminating this specific bias. To do so, we look at the coefficient on an interaction variable of $\operatorname{Euro}_{t}{ }^{*} B B R F R I_{t}{ }^{*} E D P_{t}$, a dummy variable for membership in the euro area, the budget balance FRI, and a dummy variable for violation of the 
3\% limit. In columns (3) and (4) of Table 8, we include this interaction along with Euro $_{t}{ }^{*} E D P_{t}$, a dummy for euro membership, a dummy for violation of the EDP and the output gap. We find that the coefficient on the $\operatorname{Euro}_{t}{ }^{*} E D P_{t}$ variable is large, positive, and significant, confirming the earlier result that euro area member forecasts are particularly biased when made at a time when the deficit is larger than the $3 \%$ cap. However, this effect is indeed greatly reduced if the country has fiscal rules, as seen by the coefficient on $\operatorname{Euro}_{t}{ }^{*} B B R F R I_{t} * E D P_{t}$.

Based on the point estimates, if a euro country violating the EDP limit were to go from having no fiscal rule to adopting a rule as strong as Britain's Golden Rule, we estimate that forecast bias at the one-year horizon would be no more optimistic than that of a non-euro area country that is not in violation of the EDP limit $(0.155+0.196+2.725-3.896)$. This is also the case for the two-year horizon. This is particularly interesting because even non-euro area countries have very biased forecasts when they have deficits large enough that they would violate the 3\% limit (the coefficient on the EDP dummy is over 1). Therefore, strong fiscal rules can counteract not just the bias among euro area countries, but also the bias that other countries with comparably large deficits face. In columns 5 and 6 we repeat the analysis of columns 3 and 4 but include all possible interaction terms of EDP violation, budget balance rules, and euro area membership. The coefficients are nearly unchanged from columns 3 and 4 , though the individual coefficients lose some significance. In Table A7 of the Online Appendix, we see the results are even more stark when the deficit is used as a covariate rather than the budget balance.

\section{Independent fiscal institutions and the SGP}

In this section, we consider the effect of combining budget balance rules with independent government forecasts. As described in Frankel (2011b), the Chilean government has 
been successful in combining fiscal rules with a legal requirement to use forecasts of a panel of independent experts in the government budget process. The European Commission has a database on the role of independent fiscal institutions in the budgetary processes across EU member states. ${ }^{23}$ Unfortunately it is not possible to create a proper time series as in the case of the national budget balance rules. ${ }^{24}$

For each EU member, if the country has an independent fiscal institution the database includes its date of creation, whether the government is required to consult with it during the budgetary process, whether it is generally consulted despite the lack of a legal obligation, whether it provides an analysis of fiscal policy with or without normative judgment, whether it provides independent macroeconomic or budgetary forecasts, how the government is required to use its forecasts during the budgetary process, and several other pieces of information.

In Table 9 we limit ourselves to using only one dimension of the database: whether a country has an independent fiscal institution that provides independent forecasts of the general government budget balance. We would have liked to examine the impact of the government being legally bound to use these forecasts, as in Chile; but no country in the European Union has a legal or constitutional obligation to use the independent forecasts. ${ }^{25}$

Therefore, we are limited to analyzing the effect that the existence of an independent fiscal institution making independent forecasts has on the government's own forecasts. In Table

\footnotetext{
${ }^{23}$ Available at http://ec.europa.eu/economy_finance/db_indicators/fiscal_governance/independent_institutions/index_en.htm. The European Commission defines independent fiscal institutions as "non partisan public bodies, other than the central bank, government or parliament that prepare macroeconomic forecasts for the budget, monitor fiscal performance and/or advise the government on fiscal policy matters." The EC notes that one of the benefits of these institutions is that they "can provide macroeconomic forecasts for the budget preparation that do not suffer from the optimistic biases often found in official government forecasts."

${ }^{24}$ Other than through the dates the independent fiscal institutions were founded, the database does not include whether the tasks performed by the institution or its legal position has changed since its inception. Therefore, we assume that these characteristics are unchanged since the institutions were created.

${ }^{25}$ In Austria, the government needs to justify publicly deviations from the forecasts of the Austrian Institute of Economic Research.
} 
$8, I N D F B B_{t}$ is a dummy variable that takes the value 1 if the country has an independent fiscal institution that provides independent budget balance forecasts at time $t .^{26}$ In Columns (1) and (2) of Table 9, conditional on the current output gap, budget balance, euro area membership, and interaction terms, the forecasting bias is reduced by over $2 \%$ of GDP at both horizons in euro members when independent fiscal institutions provide independent budget balance forecasts.

In columns (3) and (4) of Table 9, we examine whether independent forecasts can be helpful in overcoming the tendency of euro area countries to offer more biased budget forecasts when they are in violation of the 3\% SGP limit. In columns (3) and (4) of Table 9, we see this is in fact the case: although euro area countries violating the EDP at the time a forecast is made $\left(E u r o t * E D P_{t}\right)$ offer more optimistic forecasts, this bias is reduced for euro area countries violating the EDP that have independent budget forecasts $\left(\right.$ Euro $\left._{t} * \operatorname{Ind} F B B_{t} * E D P_{t}\right)$. It is unclear why the direct effect of independent forecasts and violations of the $\operatorname{EDP}\left(\operatorname{Ind} F B B_{t} * E D P_{t}\right)$ is so strong at the two-year horizon. But even this strong effect is more than reversed by the effect for Euro $_{t} *$ Ind $F B B_{t} * E D P_{t}$.

The regressions show that euro area governments making forecasts while in violation of the EDP with an independent fiscal institution that makes independent budget forecasts have a mean bias that is smaller by $2.7 \%$ of GDP at the one-year horizon and $2.8 \%$ of GDP at the twoyear horizon, compared to a euro area country violating the EDP without such an independent fiscal institution.

The causal interpretation of these results must be qualified: countries that place a high value on the integrity of the forecasts may be less inclined to bias their budget forecasts and may

\footnotetext{
${ }^{26}$ In constructing this variable, we assume that if the independent fiscal institution provides independent forecasts, as of 2010, it provided these forecasts since the institution's creation.
} 
be more inclined to adopt national fiscal rules or create independent fiscal institutions compared to other countries.

\section{Conclusion}

Our two most important conclusions can be stated succinctly. First, euro area countries appear to have responded to the $3 \%$ limit imposed by the Stability and Growth Pact by offering over-optimistic forecasts when they are most in danger of breaching the limit. Second, national budget balance rules or independent fiscal institutions that provide their own independent forecasts help to reduce this bias.

\section{References}

Alesina, Alberto, Ricardo Hausmann, Rudolf Hommes, and Ernesto Stein, 1999, "Budget Institutions and Fiscal Performance in Latin America," Journal of Development Economics, Vol. 59(2), 253-273.

Anderson, Barry, and Joseph Minarik, 2006, "Design Choices for Fiscal Policy Rules," OECD Journal on Budgeting vol.5, no.4, 159-208.

Ashiya, Mashahiro, 2005, “Twenty-two Years of Japanese Institutional Forecasts,” Applied Financial Economics Letters 1, no. 2, pp. 79-84.

Ashiya, Mashahiro, 2007, "Forecast Accuracy of the Japanese Government: Its Year-Ahead GDP Forecast is Too Optimistic," Japan and the World Economy 19, no. 1, January, 68-85.

Auerbach, Alan, 1994, “The U.S. Fiscal Problem: Where We are, How We Got Here and Where We're Going," NBER Macroeconomics Annual 1994, Volume 9, pp. 141-186.

---- 1999, “On the Performance and Use of Government Revenue Forecasts,” National Tax Journal, vol.52, no.4, pp. 765-782.

Beetsma, Roel, Benjamin Bluhm, Massimo Giuliodori and Peter Wierts, 2011, "From First-Release to Ex-Post Fiscal Data: Exploring the Sources of Revision Errors in the EU," CEPR Discussion Paper 8413. London: Centre for Economic Policy Research.

Beetsma, Roel, Massimo Giuliodori, and Peter Wierts, 2009, "Planning to Cheat: EU Fiscal Policy in Real Time," Economic Policy 24, 60, 753-804. 
Brück, Tilman, and Andreas Stephan, 2006, "Do Eurozone Countries Cheat with their Budget Deficit Forecasts?" Kyklos 59, no. 1, Feb., 3-15.

Buti, M., D Franco and H Ongena, 1998, "Fiscal Discipline and Flexibility in EMU: The Implementation of the Stability and Growth Pact," Oxford Review of Economic Policy, 14 (3): 81-97.

Debrun, Xavier, Laurent Moulin, Alessandro Turrini, Joaquim Ayuso-i-Casals, and Manmohan Kumar, 2008, "Tied to the Mast? National Fiscal Rules in the European Union," Economic Policy, Vol 23, Issue 54, April: 297-362.

Forni, Lorenzo, and Sandro Momigliano, 2004, "Cyclical Sensitivity of Fiscal Policies Based on Real-Time Data", (Economic Working Papers 540). Rome: Bank of Italy, Economic Research and International Relations Area.

Frankel, Jeffrey, 2011a. "Over-optimism in Forecasts by Official Budget Agencies and Its Implications." Oxford Review of Economic Policy, No. 4, Vol. 27, pp. 536-562.

Frankel, Jeffrey, 2011b, "A Solution to Fiscal Procyclicality: the Structural Budget Institutions Pioneered by Chile." Journal Economía Chilena (The Chilean Economy), vol. 14(2), pages 39-78.

Frendreis, John, and Raymond Tatalovich, 2000, "Accuracy and Bias in Macroeconomic Forecasting by the Administration, the CBO, and the Federal Reserve Board," Polity Vol. 32, No. 4 (Summer), pp. 623-632.

International Monetary Fund, 2009. "Fiscal Rules--Anchoring Expectations for Sustainable Public Finances." IMF Working Paper, Washington, DC.: International Monetary Fund.

Jonung, Lars, and Martin Larch, 2006, "Improving Fiscal Policy in the EU: The Case for Independent Forecasts," Economic Policy, 21(47), pp. 491-534.

Kopits, George, 2001, “Fiscal Rules: Useful Policy Framework Or Unnecessary Ornament?” (IMF Working Paper No. 01/145). Washington, DC.: International Monetary Fund.

Kopits, George, and Steven Symansky 1998. "Fiscal Policy Rules.” IMF Occasional Paper 162.

Marinheiro, Carlos. 2010, "The Stability and Growth Pact, Fiscal Policy Institutions and Stabilization in Europe," International Economics and Economic Policy, vol. 5(1), July, pp. 189-207

McNab, Robert M., Mark Rider, Kent Wall, 2007, ”Are Errors in Official US Budget Receipts Forecasts Just Noise?” Andrew Young School Research Paper Series Working Paper 07-22, April.

McNees, Stephen, 1995, “An Assessment of the "Official” Economic Forecasts," New England Economic Review, available at http://www.bos.frb.org/economic/neer/neer1995/neer495b.htm

Milesi-Ferretti , Gian Maria, 2004, "Good, Bad or Ugly? On the Effects of Fiscal Rules with Creative Accounting," Journal of Public Economics, 88, Issues 1-2, January, pp. 377-394.

Mühleisen, Martin, Stephan Danninger, David Hauner, Kornélia Krajnyák, and Bennett Sutton, 2005, "How Do Canadian Budget Forecasts Compare With Those of Other Industrial Countries?” IMF Working Paper 05/66, April.

O'Neill, Tim, 2005, Review of Canadian Fiscal Forecasting: Processes and System, available at http://www.fin.gc.ca/toc/2005/oneil_-eng.asp

Persson, Torsten, and Guido Tabellini, 2004, "Constitutional Rules and Fiscal Policy Outcomes," American Economic Review, 94, Number 1, March, pp. 25-45.

Poterba, James, 1997, “Do Budget Rules Work?” in A.Auerbach ed., Fiscal Policy: Lessons From Empirical Research (Cambridge: MIT Press). pp.53-86. 
Schaechter, Andrea, Tidiane Kinda, Nina Budina and Anke Weber, 2012, "Fiscal Rules in Response to the CrisisToward the 'Next-Generation' Rules. A New Dataset.” IMF Working Paper 12/187, Washington, DC.: International Monetary Fund.

Strauch, Rolf, Mark Hallerberg and Jurgen von Hagen, 2009, 'How Forms of Fiscal Governance Affect Fiscal Performance', in Hallerberg, Mark, Rolf Strauch, and Jurgen von Hagen (eds), Fiscal Governance in Europe, Cambridge, Cambridge University Press

Sutherland, Douglas, Robert Price, and Isabelle Journard, 2005, "Fiscal Rules for Sub-Central Governments: Design and Impact." (OECD Working Paper 52). Paris: Organisation for Economic Co-operation and Development.

Wyplosz, Charles, 2005, "Fiscal Policy: Institutions Versus Rules," National Institute Economic Review vol.191, no.1, January pp.64-78.

Zlatinova, Snezhana, and Max Otto, 2012, "Fixing Budget Deficits in the EU: An Evaluation of Key Issues and Proposed Modifications for Fiscal Rules in the Eurozone," Second Year Policy Analysis, MPA/ID Program, Harvard Kennedy School, March. 


\section{Tables and Figures}

Table 1: Budget Balance Forecasts and Realizations, All years

\begin{tabular}{|c|c|c|c|c|c|c|}
\hline VARIABLES & $\begin{array}{c}(1) \\
F B B I_{t+1}\end{array}$ & $\begin{array}{c}(2) \\
B B I_{t+1} \\
\end{array}$ & $\begin{array}{c}(3) \\
F B B I_{t+2} \\
\end{array}$ & $\begin{array}{c}(4) \\
B B I_{t+2} \\
\end{array}$ & $\begin{array}{c}(5) \\
F B B I_{t+3} \\
\end{array}$ & $\begin{array}{c}(6) \\
B B I_{t+3} \\
\end{array}$ \\
\hline$B B_{t}$ & $\begin{array}{c}-0.289 * * \\
(0.104)\end{array}$ & $\begin{array}{c}-0.0895 * * \\
(0.0419)\end{array}$ & $\begin{array}{c}-0.464 * * * \\
(0.0645)\end{array}$ & $\begin{array}{l}-0.154 \\
(0.111)\end{array}$ & $\begin{array}{c}-0.582 * * * \\
(0.0665)\end{array}$ & $\begin{array}{l}-0.127 \\
(0.241)\end{array}$ \\
\hline$O G_{t}$ & $\begin{array}{c}0.0743 \\
(0.0906)\end{array}$ & $\begin{array}{c}-0.563 * * * \\
(0.107)\end{array}$ & $\begin{array}{l}0.0777 \\
(0.101)\end{array}$ & $\begin{array}{l}-0.274 \\
(0.235)\end{array}$ & $\begin{array}{c}-0.0148 \\
(0.0756)\end{array}$ & $\begin{array}{c}1.014 * * * \\
(0.240)\end{array}$ \\
\hline Constant & $\begin{array}{c}-0.0414 \\
(0.290)\end{array}$ & $\begin{array}{l}-0.269 \\
(0.154)\end{array}$ & $\begin{array}{l}-0.118 \\
(0.170)\end{array}$ & $\begin{array}{c}-0.0706 \\
(0.119)\end{array}$ & $\begin{array}{c}0.317 \\
(0.205)\end{array}$ & $\begin{array}{c}-0.294 * * \\
(0.109)\end{array}$ \\
\hline Observations & 243 & 243 & 210 & 210 & 164 & 164 \\
\hline R-squared & 0.411 & 0.136 & 0.562 & 0.042 & 0.664 & 0.047 \\
\hline Countries & 17 & 17 & 16 & 16 & 15 & 15 \\
\hline Year FE & No & No & No & No & No & No \\
\hline
\end{tabular}

Robust standard errors in parentheses, clustered at the country level.

$* * *, * *$, and $*$ denote significance at the level of 1,5 , and $10 \%$, respectively.

Notes: European countries.

Table 2: Budget Balance Forecasts and Realizations, All years

\begin{tabular}{lcccccc}
\hline & $(1)$ & $(2)$ & $(3)$ & $(4)$ & $(5)$ & $(6)$ \\
VARIABLES & $F B B I_{t+1}$ & $B B I_{t+1}$ & $F B B I_{t+2}$ & $B B I_{t+2}$ & $F B B I_{t+3}$ & $B B I_{t+3}$ \\
\hline & & & & & & \\
Surplus $_{t} * B B_{t}$ & -0.0647 & 0.0148 & $-0.466^{* * *}$ & 0.0936 & $-0.452^{* * *}$ & 0.142 \\
& $(0.0569)$ & $(0.0213)$ & $(0.0643)$ & $(0.206)$ & $(0.0929)$ & $(0.280)$ \\
Deficit $^{*} B B_{t}$ & $-0.465^{* * *}$ & $-0.172 * * *$ & $-0.463 * * *$ & -0.238 & $-0.672 * * *$ & -0.314 \\
& $(0.0930)$ & $(0.0469)$ & $(0.0869)$ & $(0.212)$ & $(0.113)$ & $(0.610)$ \\
OG $_{t}$ & $0.101^{*}$ & $-0.550^{* * *}$ & 0.0780 & -0.315 & -0.0511 & $0.938^{* * *}$ \\
& $(0.0568)$ & $(0.0980)$ & $(0.0948)$ & $(0.276)$ & $(0.0689)$ & $(0.153)$ \\
Constant & $-0.749 * *$ & $-0.598 * *$ & -0.116 & -0.434 & 0.0717 & -0.805 \\
& $(0.264)$ & $(0.214)$ & $(0.223)$ & $(0.500)$ & $(0.299)$ & $(1.019)$ \\
Observations & & & & & & 164 \\
R-squared & 243 & 243 & 210 & 210 & 164 & 164 \\
Countries & 0.522 & 0.152 & 0.562 & 0.049 & 0.671 & 0.051 \\
Year FE & 17 & 17 & 16 & 16 & 15 & 15 \\
\hline
\end{tabular}

Robust standard errors in parentheses, clustered at the country level. $* * *, * *$, and $*$ denote significance at the level of 1,5 , and $10 \%$, respectively.

Notes: European countries. 
Table 3: Errors in Forecasting Budget Balance and Growth

\begin{tabular}{|c|c|c|c|c|c|c|}
\hline VARIABLES & $\begin{array}{c}(1) \\
B B E_{t+1} \\
\end{array}$ & $\begin{array}{c}(2) \\
B B E_{t+2} \\
\end{array}$ & $\begin{array}{c}(3) \\
B B E_{t+3} \\
\end{array}$ & $\begin{array}{c}(4) \\
G D P E_{t+1}\end{array}$ & $\begin{array}{c}(5) \\
G D P E_{t+2} \\
\end{array}$ & $\begin{array}{c}(6) \\
G D P E_{t+3} \\
\end{array}$ \\
\hline$B B_{t}$ & $\begin{array}{c}-0.199 * * \\
(0.0689)\end{array}$ & $\begin{array}{c}-0.346^{* * * *} \\
(0.104)\end{array}$ & $\begin{array}{c}-0.401 * * * \\
(0.110)\end{array}$ & $\begin{array}{c}-0.0594 \\
(0.0450)\end{array}$ & $\begin{array}{c}-0.161 * * * \\
(0.0391)\end{array}$ & $\begin{array}{c}-0.124 \\
(0.0928)\end{array}$ \\
\hline$O G_{t}$ & $\begin{array}{c}0.637 * * * \\
(0.114)\end{array}$ & $\begin{array}{c}1.418 * * * \\
(0.292)\end{array}$ & $\begin{array}{c}1.875^{* * *} * \\
(0.409)\end{array}$ & $\begin{array}{c}0.947 * * * \\
(0.0754)\end{array}$ & $\begin{array}{c}1.010 * * * \\
(0.0878)\end{array}$ & $\begin{array}{c}0.457 * * * \\
(0.146)\end{array}$ \\
\hline Constant & $\begin{array}{c}0.227 \\
(0.230)\end{array}$ & $\begin{array}{c}0.533 * * \\
(0.199)\end{array}$ & $\begin{array}{c}1.360 * * * \\
(0.287)\end{array}$ & $\begin{array}{l}0.303^{*} \\
(0.154)\end{array}$ & $\begin{array}{c}0.534 * * * \\
(0.121)\end{array}$ & $\begin{array}{c}1.018 * * * \\
(0.180)\end{array}$ \\
\hline Observations & 243 & 210 & 164 & 239 & 209 & 164 \\
\hline R-squared & 0.190 & 0.343 & 0.368 & 0.453 & 0.326 & 0.055 \\
\hline Countries & 17 & 16 & 15 & 17 & 16 & 15 \\
\hline Year FE & No & No & No & No & No & No \\
\hline
\end{tabular}

Robust standard errors in parentheses, clustered at the country level.

$* * *, * *$, and $*$ denote significance at the level of 1,5 , and $10 \%$, respectively.

Notes: European countries.

Table 4: Errors in Forecasting Budget Balance

\begin{tabular}{lccc}
\hline & $(1)$ & $(2)$ & $(3)$ \\
VARIABLES & $B B E_{t+1}$ & $B B E_{t+2}$ & $B B E_{t+3}$ \\
\hline & & & \\
Surplus $_{t} * B B_{t}$ & -0.0795 & $-0.295^{* *}$ & -0.175 \\
& $(0.0573)$ & $(0.108)$ & $(0.171)$ \\
${\text { Deficit } * B B_{t}}$ & $-0.293 * * *$ & $-0.363 * *$ & $-0.558^{* * *}$ \\
& $(0.0645)$ & $(0.134)$ & $(0.180)$ \\
OG $_{t}$ & $0.651 * * *$ & $1.409 * * *$ & $1.812^{* * *}$ \\
& $(0.113)$ & $(0.281)$ & $(0.452)$ \\
Constant & -0.150 & 0.459 & $0.932 * *$ \\
& $(0.169)$ & $(0.274)$ & $(0.404)$ \\
& & & \\
Observations & 243 & 210 & 164 \\
R-squared & 0.213 & 0.344 & 0.374 \\
Countries & 17 & 16 & 15 \\
Year FE & No & No & No \\
\hline
\end{tabular}

Robust standard errors in parentheses, clustered at the country level. $* * *, * *$, and $*$ denote significance at the level of 1,5 , and $10 \%$, respectively.

Notes: European countries. 
Table 5, Panel 1: The Euro and Budget Balance Forecast Errors, One year ahead

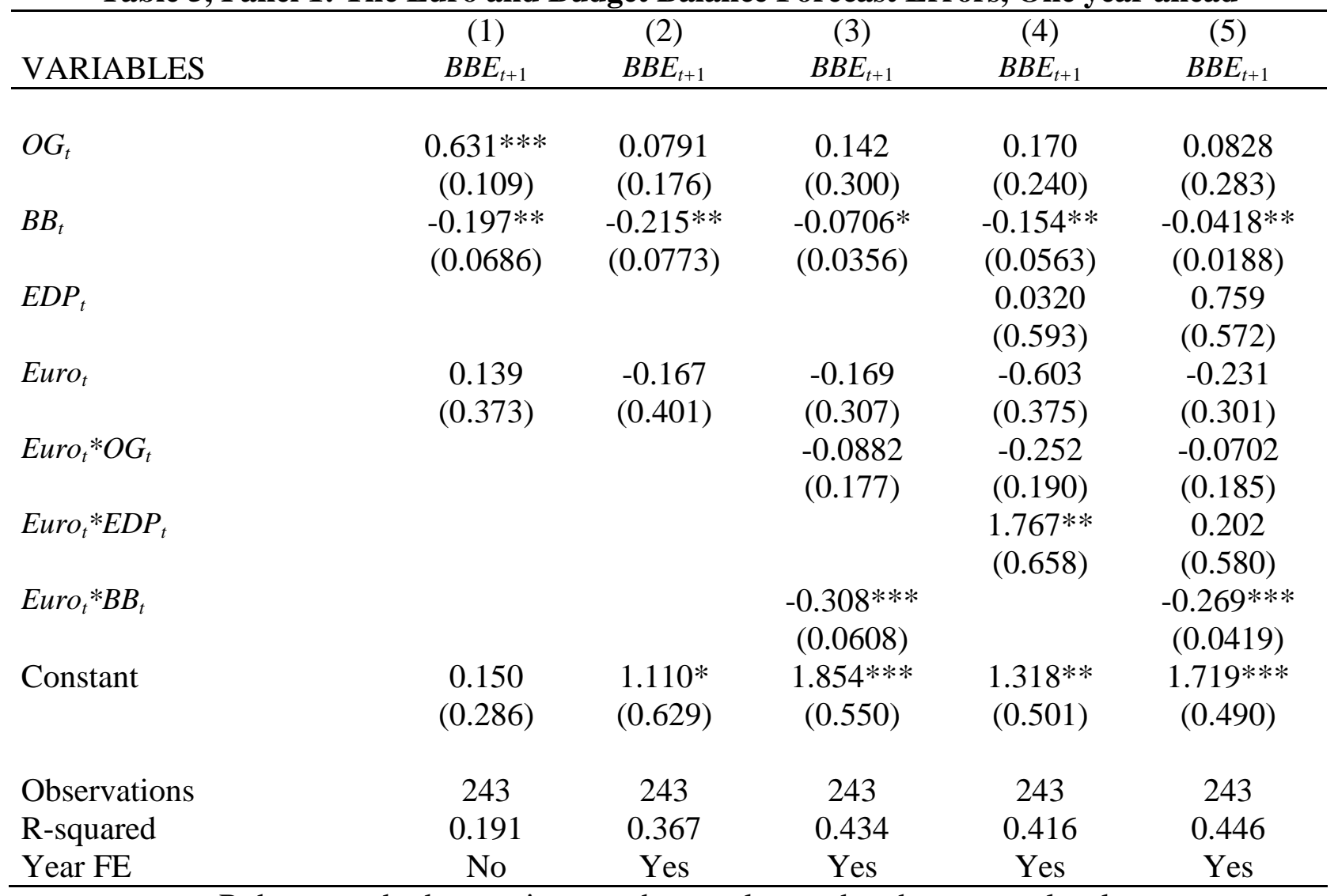
Robust standard errors in parentheses, clustered at the country level. $* * *, * *$, and $*$ denote significance at the level of 1,5 , and $10 \%$, respectively.

Notes: European Countries 
Table 5, Panel 2: The Euro and Budget Balance Forecast Errors, Two years ahead

\begin{tabular}{|c|c|c|c|c|c|}
\hline VARIABLES & $\begin{array}{c}(6) \\
B B E_{t+2} \\
\end{array}$ & $\begin{array}{c}(7) \\
B B E_{t+2} \\
\end{array}$ & $\begin{array}{c}(8) \\
B B E_{t+2} \\
\end{array}$ & $\begin{array}{c}(9) \\
B B E_{t+2} \\
\end{array}$ & $\begin{array}{c}(10) \\
B B E_{t+2} \\
\end{array}$ \\
\hline$O G_{t}$ & $\begin{array}{c}1.398 * * * \\
(0.287)\end{array}$ & $\begin{array}{c}0.408 \\
(0.365)\end{array}$ & $\begin{array}{c}0.107 \\
(0.334)\end{array}$ & $\begin{array}{c}0.106 \\
(0.265)\end{array}$ & $\begin{array}{l}0.0194 \\
(0.296)\end{array}$ \\
\hline$B B_{t}$ & $\begin{array}{c}-0.345^{* * *} * \\
(0.0988)\end{array}$ & $\begin{array}{c}-0.401 * * * \\
(0.111)\end{array}$ & $\begin{array}{c}-0.206^{*} \\
(0.114)\end{array}$ & $\begin{array}{c}-0.233^{* *} \\
(0.0903)\end{array}$ & $\begin{array}{l}-0.127 \\
(0.137)\end{array}$ \\
\hline$E D P_{t}$ & & & & $\begin{array}{c}0.254 \\
(0.784)\end{array}$ & $\begin{array}{c}0.833 \\
(0.948)\end{array}$ \\
\hline Euro $_{t}$ & $\begin{array}{c}0.893 \\
(0.526)\end{array}$ & $\begin{array}{r}-0.0485 \\
(0.320)\end{array}$ & $\begin{array}{l}-0.217 \\
(0.384)\end{array}$ & $\begin{array}{l}-0.622 \\
(0.355)\end{array}$ & $\begin{array}{l}-0.514 \\
(0.375)\end{array}$ \\
\hline Euro $_{t} * O G_{t}$ & & & $\begin{array}{c}0.340 \\
(0.367)\end{array}$ & $\begin{array}{c}0.279 \\
(0.337)\end{array}$ & $\begin{array}{c}0.373 \\
(0.362)\end{array}$ \\
\hline Euro $_{t}{ }^{*} E D P_{t}$ & & & & $\begin{array}{l}2.160 * \\
(1.020)\end{array}$ & $\begin{array}{c}1.324 \\
(1.096)\end{array}$ \\
\hline Euro $_{t} * B B_{t}$ & & & $\begin{array}{c}-0.288^{* *} \\
(0.122)\end{array}$ & & $\begin{array}{l}-0.155 \\
(0.139)\end{array}$ \\
\hline Constant & $\begin{array}{l}-0.0172 \\
(0.365)\end{array}$ & $\begin{array}{c}0.847 \\
(1.100)\end{array}$ & $\begin{array}{c}2.370 * * * \\
(0.788)\end{array}$ & $\begin{array}{c}2.090 * * \\
(0.786)\end{array}$ & $\begin{array}{c}2.526 * * * \\
(0.815)\end{array}$ \\
\hline Observations & 210 & 210 & 210 & 210 & 210 \\
\hline R-squared & 0.358 & 0.503 & 0.517 & 0.538 & 0.540 \\
\hline Year FE & No & Yes & Yes & Yes & Yes \\
\hline
\end{tabular}

Robust standard errors in parentheses, clustered at the country level. $* * *, * *$, and $*$ denote significance at the level of 1,5 , and $10 \%$, respectively.

Notes: European countries. 
Table 6: The Euro and Budget Balance Forecast Errors

\begin{tabular}{|c|c|c|c|c|}
\hline VARIABLES & $\begin{array}{c}(1) \\
B B E_{t+1} \\
\end{array}$ & $\begin{array}{c}(2) \\
B B E_{t+1} \\
\end{array}$ & $\begin{array}{c}(3) \\
B B E_{t+2} \\
\end{array}$ & $\begin{array}{c}(4) \\
B B E_{t+2} \\
\end{array}$ \\
\hline$O G_{t}$ & $\begin{array}{c}0.154 \\
(0.306)\end{array}$ & $\begin{array}{c}0.123 \\
(0.303)\end{array}$ & $\begin{array}{c}-0.0463 \\
(0.317)\end{array}$ & $\begin{array}{c}-0.00755 \\
(0.314)\end{array}$ \\
\hline$B B_{t}$ & $\begin{array}{c}-0.173 * * \\
(0.0801)\end{array}$ & $\begin{array}{c}-0.102 * * \\
(0.0464)\end{array}$ & $\begin{array}{c}-0.392 * * * \\
(0.0857)\end{array}$ & $\begin{array}{c}-0.510 * * * \\
(0.0871)\end{array}$ \\
\hline EDPGap $_{t}$ & $\begin{array}{l}0.269 * \\
(0.140)\end{array}$ & $\begin{array}{c}0.170 \\
(0.119)\end{array}$ & $\begin{array}{c}0.468 * * * \\
(0.105)\end{array}$ & $\begin{array}{c}0.608 * * * \\
(0.122)\end{array}$ \\
\hline Euro $_{t}$ & $\begin{array}{c}-0.338 \\
(0.363)\end{array}$ & $\begin{array}{c}-0.293 \\
(0.323)\end{array}$ & $\begin{array}{l}-0.417 \\
(0.301)\end{array}$ & $\begin{array}{l}-0.423 \\
(0.267)\end{array}$ \\
\hline Euro $_{t} * O G_{t}$ & $\begin{array}{l}-0.227 \\
(0.183)\end{array}$ & $\begin{array}{c}-0.0822 \\
(0.176)\end{array}$ & $\begin{array}{c}0.291 \\
(0.383)\end{array}$ & $\begin{array}{c}0.200 \\
(0.398)\end{array}$ \\
\hline Euro $_{t}{ }^{*}$ EDPGap ${ }_{t}$ & $\begin{array}{c}-0.509 * * * \\
(0.120)\end{array}$ & $\begin{array}{l}-0.192 \\
(0.151)\end{array}$ & $\begin{array}{c}-0.799 * * * \\
(0.174)\end{array}$ & $\begin{array}{c}-1.019 * * * \\
(0.208)\end{array}$ \\
\hline Euro $_{t} * B B_{t}$ & & $\begin{array}{c}-0.260 * * \\
(0.0992)\end{array}$ & & $\begin{array}{c}0.172 \\
(0.104)\end{array}$ \\
\hline Constant & $\begin{array}{c}2.379 * * \\
(1.078)\end{array}$ & $\begin{array}{c}2.411 * * \\
(1.094)\end{array}$ & $\begin{array}{c}3.472 * * * \\
(0.576)\end{array}$ & $\begin{array}{c}3.327 * * * \\
(0.490)\end{array}$ \\
\hline Observations & 243 & 243 & 210 & 210 \\
\hline R-squared & 0.420 & 0.438 & 0.539 & 0.541 \\
\hline Country FE & No & No & No & No \\
\hline Year FE & Yes & Yes & Yes & Yes \\
\hline
\end{tabular}

Robust standard errors in parentheses, clustered at the country level. $* * *, * *$, and $*$ denote significance at the level of 1,5 , and $10 \%$, respectively.

Notes: European countries. 
Table 7: National Budget Balance rules of the Excessive Deficit Procedure

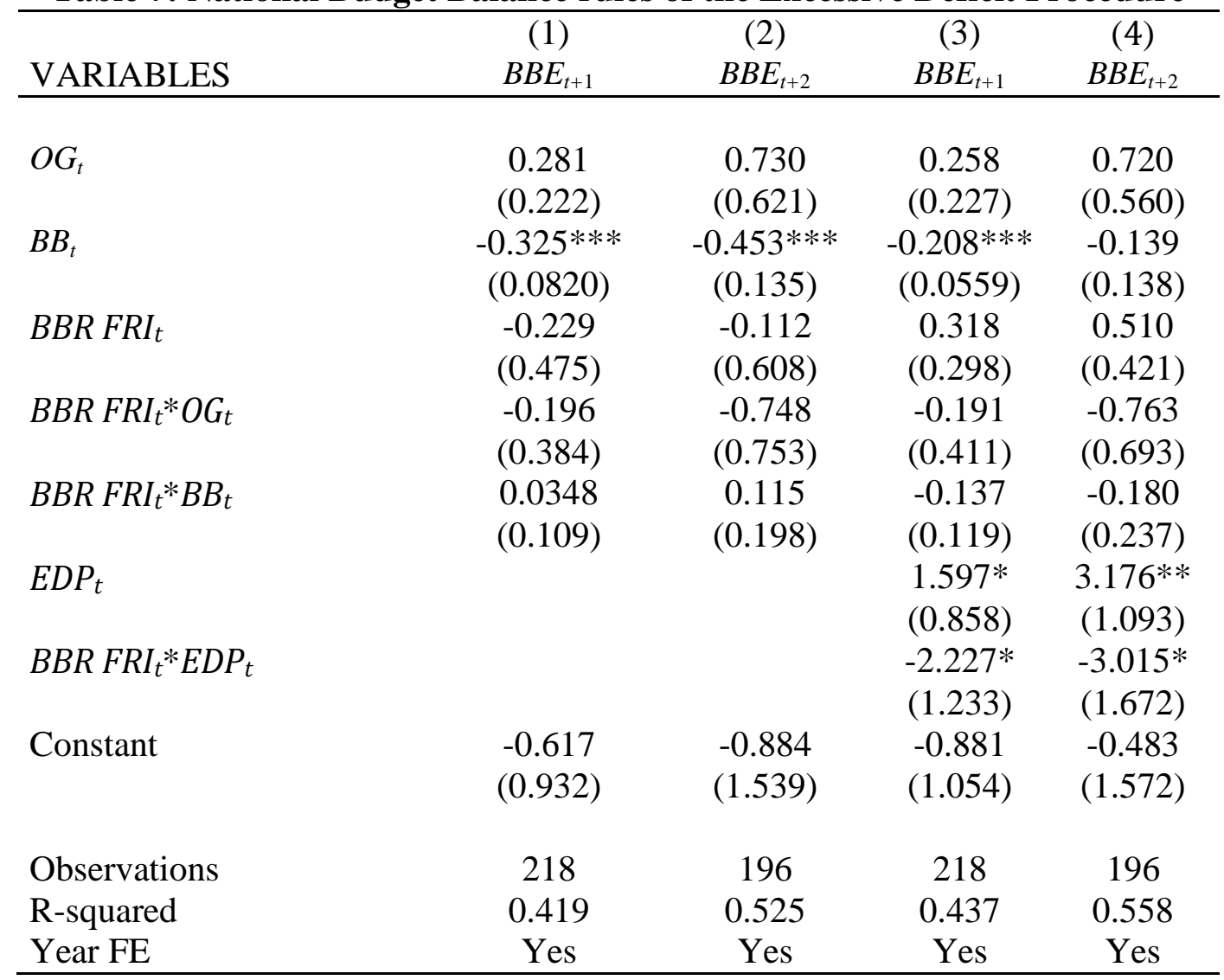

Robust standard errors in parentheses, clustered at the country level.

$* * *, * *$, and $*$ denote significance at the level of 1,5 , and $10 \%$, respectively.

Notes: EC data set countries. 
Table 8: National Budget Balances Rules, the Euro Area and the EDP

\begin{tabular}{|c|c|c|c|c|c|c|}
\hline VARIABLES & $\begin{array}{c}(1) \\
B B E_{t+1}\end{array}$ & $\begin{array}{c}(2) \\
B B E_{t+2} \\
\end{array}$ & $\begin{array}{c}(3) \\
B B E_{t+1}\end{array}$ & $\begin{array}{c}(4) \\
B B E_{t+2} \\
\end{array}$ & $\begin{array}{c}(5) \\
B B E_{t+1} \\
\end{array}$ & $\begin{array}{c}(6) \\
B B E_{t+2}\end{array}$ \\
\hline$O G_{t}$ & $\begin{array}{c}0.220 \\
(0.218)\end{array}$ & $\begin{array}{c}0.693 \\
(0.634)\end{array}$ & $\begin{array}{c}0.158 \\
(0.246)\end{array}$ & $\begin{array}{c}0.642 \\
(0.588)\end{array}$ & $\begin{array}{c}0.143 \\
(0.230)\end{array}$ & $\begin{array}{c}0.636 \\
(0.588)\end{array}$ \\
\hline$B B_{t}$ & $\begin{array}{c}-0.325 * * * \\
(0.0676)\end{array}$ & $\begin{array}{c}-0.459 * * * \\
(0.115)\end{array}$ & $\begin{array}{c}-0.187 * * * \\
(0.0513)\end{array}$ & $\begin{array}{l}-0.133 \\
(0.140)\end{array}$ & $\begin{array}{c}-0.198 * * * \\
(0.0512)\end{array}$ & $\begin{array}{l}-0.139 \\
(0.129)\end{array}$ \\
\hline$E D P_{t}$ & & & $\begin{array}{l}-0.155 \\
(0.653)\end{array}$ & $\begin{array}{c}1.345 \\
(1.082)\end{array}$ & $\begin{array}{l}-0.0591 \\
(0.971)\end{array}$ & $\begin{array}{c}1.359 \\
(1.384)\end{array}$ \\
\hline$B B R F R I_{t}$ & $\begin{array}{c}1.258 \\
(0.982)\end{array}$ & $\begin{array}{c}1.285 \\
(1.320)\end{array}$ & $\begin{array}{c}0.196 \\
(0.399)\end{array}$ & $\begin{array}{c}0.271 \\
(0.764)\end{array}$ & $\begin{array}{c}0.619 \\
(0.680)\end{array}$ & $\begin{array}{c}0.410 \\
(0.834)\end{array}$ \\
\hline Euro $_{t}$ & $\begin{array}{c}1.433 \\
(0.879)\end{array}$ & $\begin{array}{c}1.218 \\
(1.178)\end{array}$ & $\begin{array}{l}-0.335 \\
(0.407)\end{array}$ & $\begin{array}{c}-0.394 \\
(0.632)\end{array}$ & $\begin{array}{c}0.166 \\
(0.813)\end{array}$ & $\begin{array}{l}-0.230 \\
(1.063)\end{array}$ \\
\hline$B B R F R I_{t}^{*} O G_{t}$ & $\begin{array}{l}-0.148 \\
(0.377)\end{array}$ & $\begin{array}{c}-0.706 \\
(0.767)\end{array}$ & $\begin{array}{l}-0.193 \\
(0.425)\end{array}$ & $\begin{array}{l}-0.772 \\
(0.722)\end{array}$ & $\begin{array}{c}-0.182 \\
(0.409)\end{array}$ & $\begin{array}{l}-0.770 \\
(0.719)\end{array}$ \\
\hline$B B R F R I_{t}^{*} B B_{t}$ & $\begin{array}{c}0.0565 \\
(0.0668)\end{array}$ & $\begin{array}{c}0.142 \\
(0.160)\end{array}$ & $\begin{array}{c}-0.144 \\
(0.102)\end{array}$ & $\begin{array}{c}-0.173 \\
(0.202)\end{array}$ & $\begin{array}{c}-0.0998 \\
(0.101)\end{array}$ & $\begin{array}{l}-0.153 \\
(0.197)\end{array}$ \\
\hline Euro $_{t} * B B R$ FRI $_{t}$ & $\begin{array}{c}-2.514^{*} \\
(1.183)\end{array}$ & $\begin{array}{l}-2.455 \\
(1.711)\end{array}$ & & & $\begin{array}{c}-0.769 \\
(1.087)\end{array}$ & $\begin{array}{c}-0.239 \\
(1.348)\end{array}$ \\
\hline Euro $_{t}{ }^{*} E D P_{t}$ & & & $\begin{array}{c}2.725 * * \\
(1.041)\end{array}$ & $\begin{array}{l}2.721 * \\
(1.450)\end{array}$ & $\begin{array}{l}2.428 * \\
(1.176)\end{array}$ & $\begin{array}{c}2.632 \\
(1.680)\end{array}$ \\
\hline$B B R F R I_{t}^{*} E D P_{t}$ & & & & & $\begin{array}{c}0.111 \\
(1.160)\end{array}$ & $\begin{array}{l}0.0764 \\
(2.296)\end{array}$ \\
\hline Euro $_{t} * B B R F R I_{t}^{*} E D P_{t}$ & & & $\begin{array}{c}-3.896 * * \\
(1.393)\end{array}$ & $\begin{array}{c}-5.304 * * \\
(2.203)\end{array}$ & $\begin{array}{l}-3.419 * \\
(1.635)\end{array}$ & $\begin{array}{c}-5.175^{*} \\
(2.785)\end{array}$ \\
\hline Constant & $\begin{array}{c}-0.608 \\
(0.767)\end{array}$ & $\begin{array}{l}-0.956 \\
(1.323)\end{array}$ & $\begin{array}{c}1.120 \\
(1.036)\end{array}$ & $\begin{array}{c}1.425 \\
(1.519)\end{array}$ & $\begin{array}{c}0.899 \\
(1.085)\end{array}$ & $\begin{array}{c}1.334 \\
(1.565)\end{array}$ \\
\hline $\begin{array}{l}\text { Observations } \\
\text { R-squared } \\
\text { Year FE }\end{array}$ & $\begin{array}{c}218 \\
0.437 \\
\text { Yes }\end{array}$ & $\begin{array}{c}196 \\
0.535 \\
\text { Yes }\end{array}$ & $\begin{array}{c}218 \\
0.467 \\
\text { Yes }\end{array}$ & $\begin{array}{c}196 \\
0.578 \\
\text { Yes }\end{array}$ & $\begin{array}{c}218 \\
0.468 \\
\text { Yes }\end{array}$ & $\begin{array}{c}196 \\
0.578 \\
\text { Yes }\end{array}$ \\
\hline
\end{tabular}

Robust standard errors in parentheses, clustered at the country level. $* * *, * *$, and $*$ denote significance at the level of 1,5 , and $10 \%$, respectively.

Notes: EC data set countries. 
Table 9: Independent Fiscal Institutions and Forecast Errors

\begin{tabular}{|c|c|c|c|c|}
\hline & (1) & (2) & (3) & (4) \\
\hline VARIABLES & $B B E_{t+1}$ & $B B E_{t+2}$ & $B B E_{t+1}$ & $B B E_{t+2}$ \\
\hline \multirow[t]{2}{*}{$O G_{t}$} & 0.298 & 0.818 & 0.202 & 0.727 \\
\hline & $(0.188)$ & $(0.520)$ & $(0.198)$ & $(0.513)$ \\
\hline \multirow[t]{2}{*}{$B B_{t}$} & $-0.331 * * *$ & $-0.444 * * *$ & $-0.197 * * *$ & -0.204 \\
\hline & $(0.0512)$ & $(0.113)$ & $(0.0427)$ & $(0.139)$ \\
\hline \multirow[t]{2}{*}{$I N D F B B_{t}$} & $0.959 *$ & 1.007 & 0.431 & 0.403 \\
\hline & $(0.491)$ & $(0.588)$ & $(0.291)$ & $(0.450)$ \\
\hline \multirow[t]{2}{*}{ Euro $_{t}$} & $1.240 * *$ & 1.129 & 0.174 & 0.223 \\
\hline & $(0.426)$ & $(0.691)$ & $(0.311)$ & $(0.682)$ \\
\hline \multirow[t]{2}{*}{$I N D F B B_{t}^{*} O G_{t}$} & -0.146 & -0.764 & -0.0776 & -0.703 \\
\hline & $(0.231)$ & $(0.468)$ & $(0.208)$ & $(0.471)$ \\
\hline \multirow[t]{2}{*}{$I N D F B B_{t}^{*} B B_{t}$} & -0.0339 & -0.0533 & -0.111 & -0.0995 \\
\hline & $(0.0653)$ & $(0.135)$ & $(0.0792)$ & $(0.153)$ \\
\hline \multirow[t]{2}{*}{ Euro $_{t} *$ IND FBB ${ }_{t}$} & $-2.270 * * *$ & $-2.484 * *$ & $-1.107 *$ & -1.149 \\
\hline & $(0.682)$ & $(0.863)$ & $(0.537)$ & $(0.752)$ \\
\hline \multirow[t]{2}{*}{$E D P_{t}$} & & & 0.0201 & 1.431 \\
\hline & & & $(0.883)$ & $(1.147)$ \\
\hline \multirow[t]{2}{*}{ Euro $_{t} * E D P_{t}$} & & & $2.332 *$ & 1.616 \\
\hline & & & $(1.112)$ & $(1.614)$ \\
\hline \multirow[t]{2}{*}{$I N D F B B_{t} * E D P_{t}$} & & & 0.540 & $4.118 * * *$ \\
\hline & & & $(1.311)$ & $(0.975)$ \\
\hline \multirow{2}{*}{ Euro $_{t} * I N D F B B_{t} * E D P_{t}$} & & & $-2.584 *$ & $-6.195 * * *$ \\
\hline & & & $(1.418)$ & $(1.391)$ \\
\hline \multirow[t]{2}{*}{ Constant } & -0.686 & -0.785 & 0.823 & 0.526 \\
\hline & $(0.580)$ & (1.290) & $(0.818)$ & $(1.306)$ \\
\hline Observations & 218 & 196 & 218 & 196 \\
\hline R-squared & 0.465 & 0.577 & 0.497 & 0.614 \\
\hline Year FE & Yes & Yes & Yes & Yes \\
\hline
\end{tabular}

Notes: EC data set countries. 


\section{Figures}

Figure 1: Mean one-year ahead budget forecast errors, European Countries, Full Sample Period

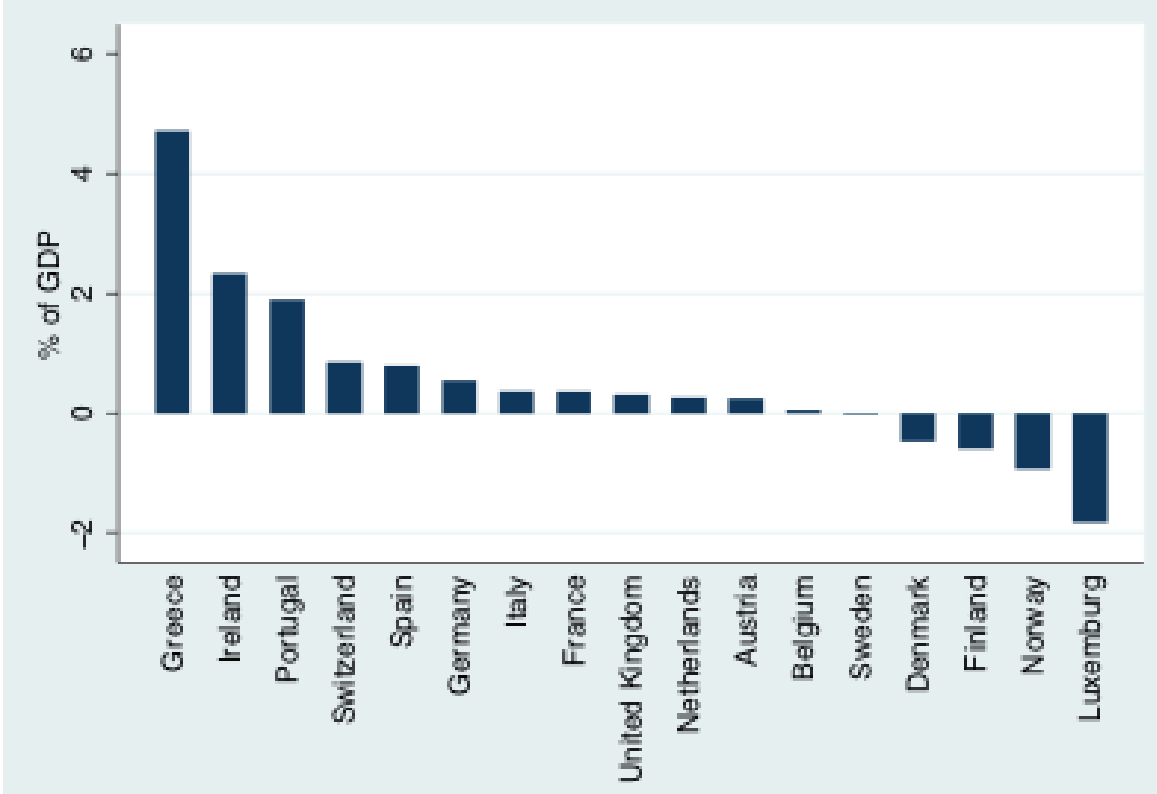

Figure 2: Mean two-year ahead budget forecast errors, European Countries, Full Sample Period

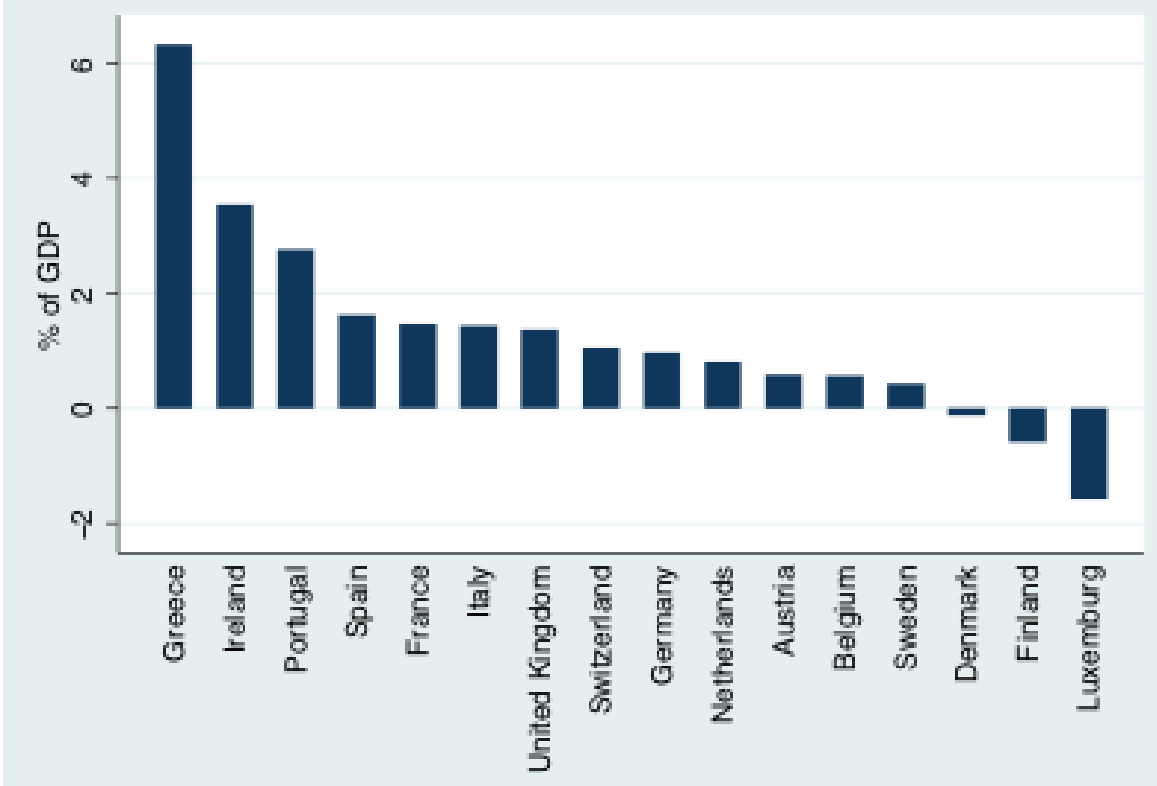


Figure 3: Mean Budget Forecast Errors, European Countries, 1995-2011

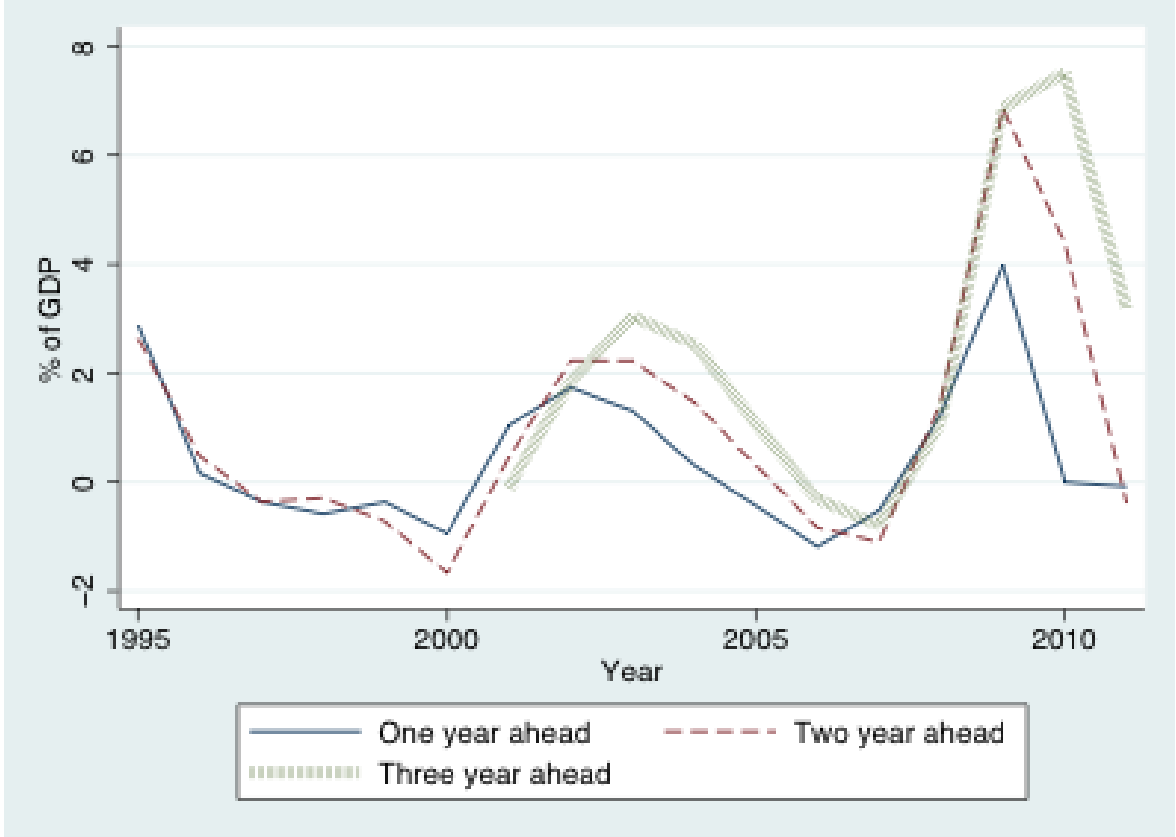

Figure 4: Mean Real GDP Growth Rate Forecast Error, European Countries, 1995-2011

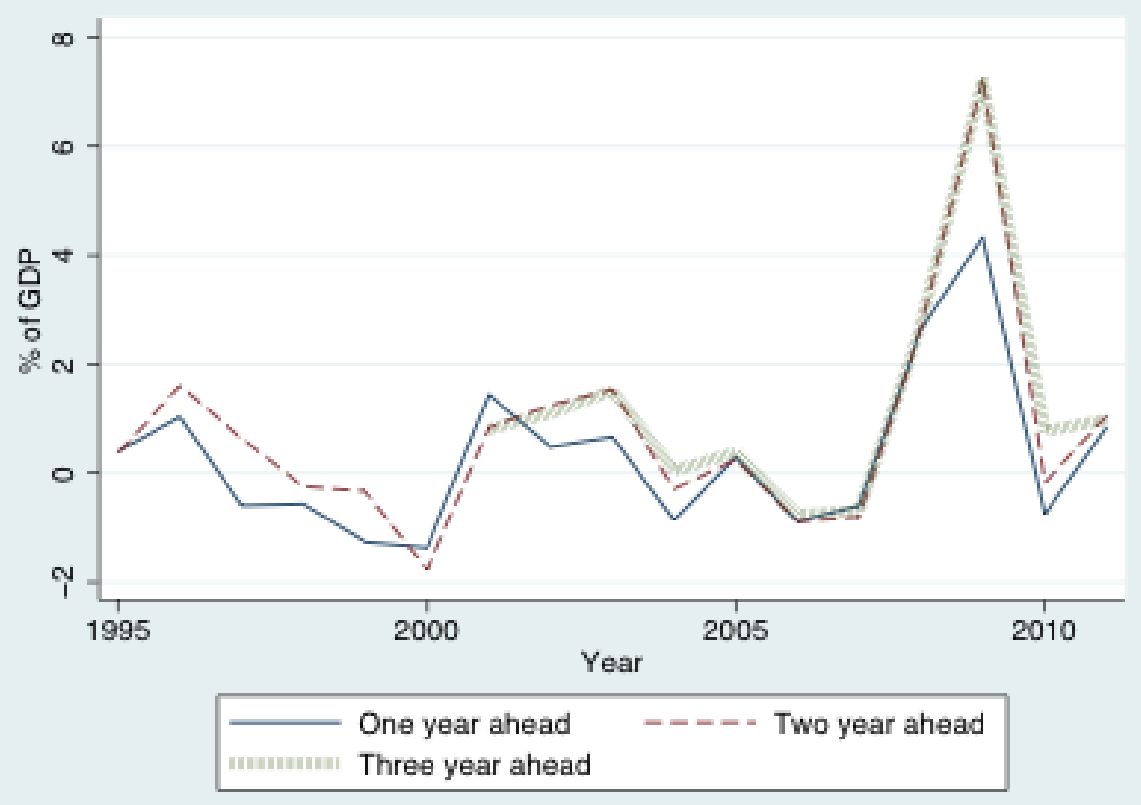


Figure 5: Budget balance forecasts and realizations: euro area v. non-euro area pre-2008
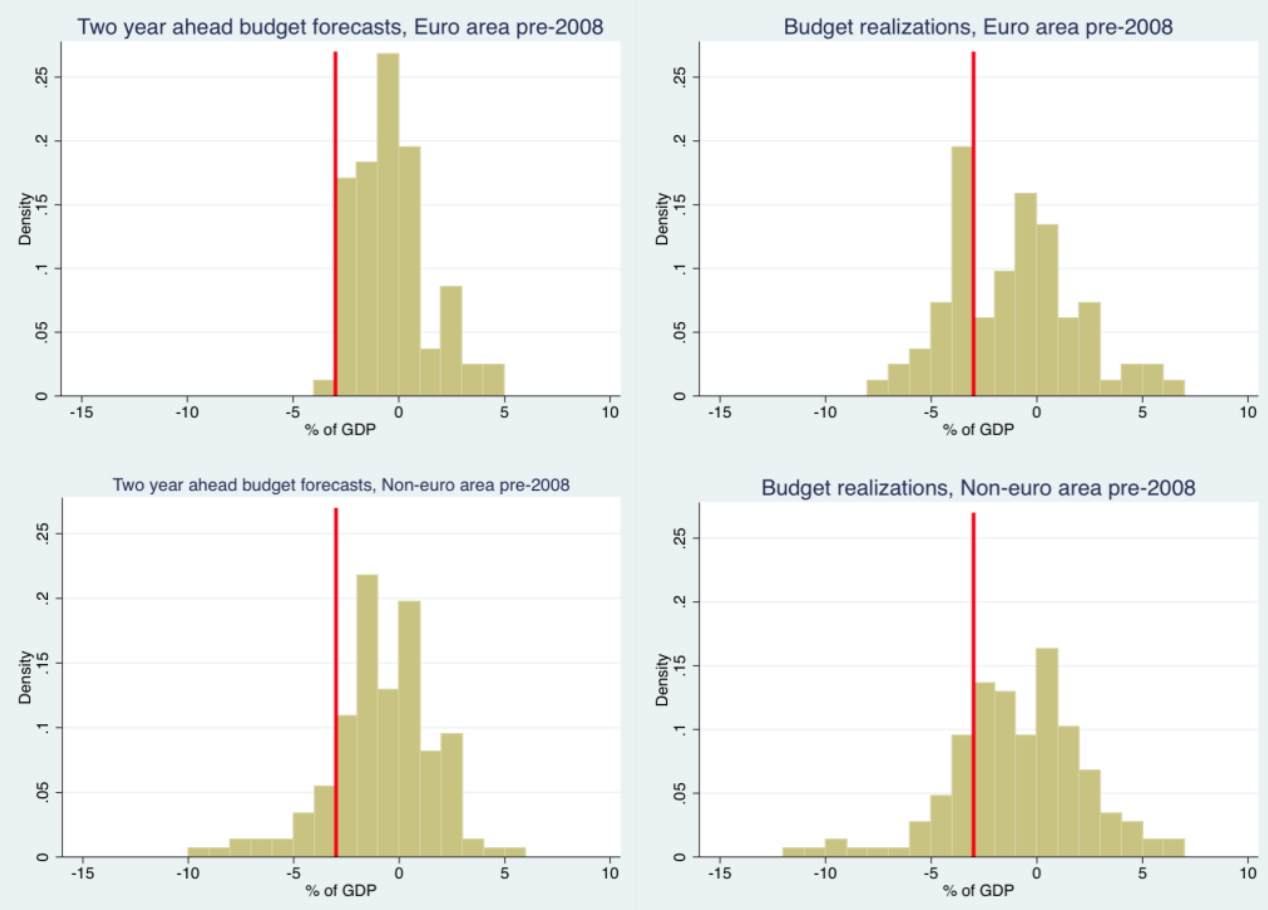

Figure 6: Fiscal Rules in the European Union, 1990-2010

\section{Fiscal Rules}
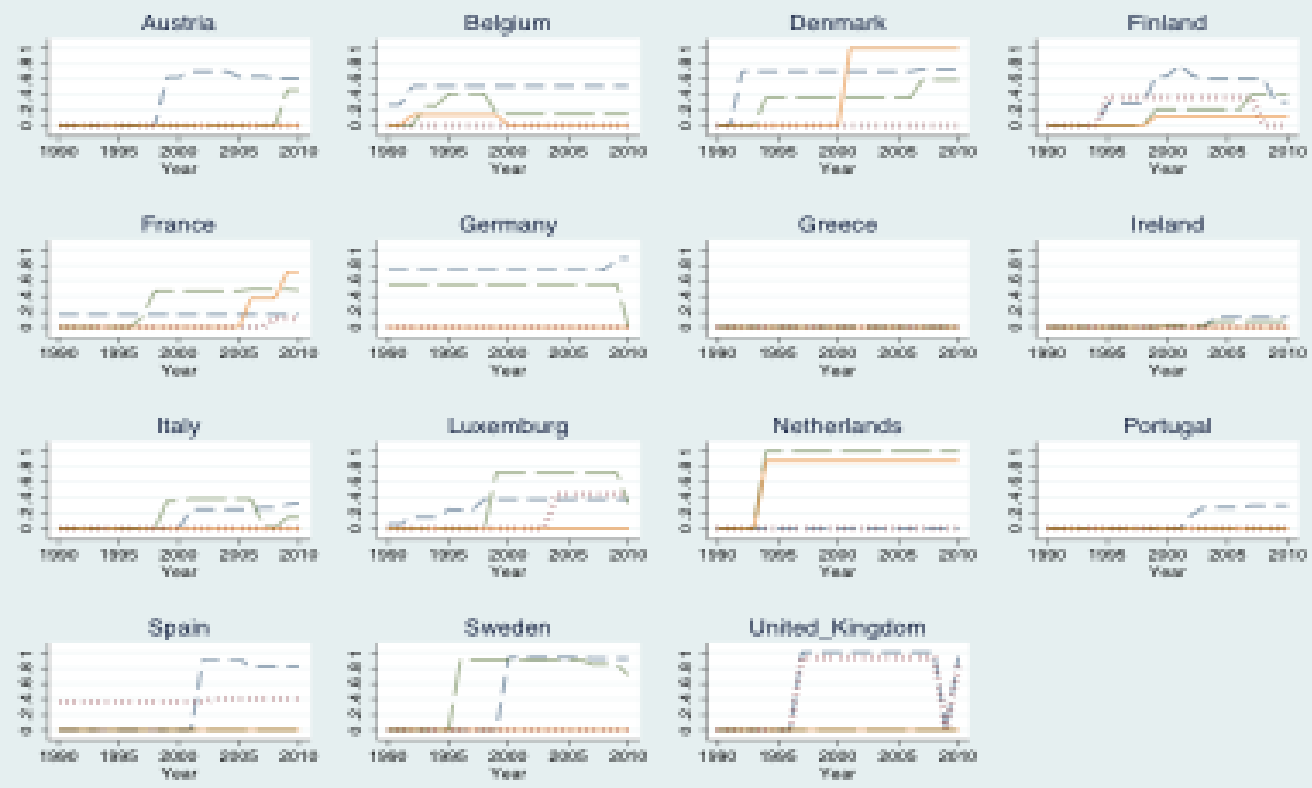

----- Budget Balance Rule

Expenditure rule

Debt Rule Revenue Rule 